were to press rather for the appointment of more consultants than to seek ways of diluting consultant responsibility by appointing people to this grade. It would appear that the College has really decided that there is a case for a sub consultant grade of psychiatrist who will carry out the duties of the Mental Health Act under Section 28.

I would have anticipated that such a move might come from community physicians, from heads of departments of Social Services and local authorities, putting pressure on the Department of Health but I do not think it is appropriate for the College to lead in this direction. It is the College's function to maintain high standards of professional practice and to ensure that consultants are appointed in sufficient numbers to carry out their duties under the Mental Health Act.

I would consider further that the College ought to have had wider advice from its membership before making such a recommendation. Indeed, any legislation in relation to mental health is considered by a very wide channel of medical opinion before being put into practice.

JOHN T. HuTCHINSON

Cane Hill Hospital

Surrey, CR3 $3 Y L$

\section{Psychiatry for the general practitioner trainee}

DeAR SIR

Your special correspondent who reported in the August Bulletin on the Joint Conference on Psychiatry for the General Practitioner Trainee has misrepresented me. I did not intend that GP trainees should spend more than six months in psychiatry. I suggested that, as an alternative to a full-time attachment, there might be a longer period of day release when they could work with the same patients over a year or so. Dr Horder takes up the same point in his letter to you. The one-day meeting was most valuable, and I hope that further discussions will take place between the two Colleges leading to closer programme building.

University Hospital of South Manchester Manchester M20 8LR

NeIL Kessel

anchester M20 8LR

\section{Recruitment to mental deficiency work \\ DeAR SIR}

We refer to the statement on Shortage of Manpower and Poor Recruitment to the Specialty of Mental Deficiency which was published with approval of the Executive and Finance Committee of the College in the April, 1980, edition of the Bulletin.

While the statement is laudable in its intent we believe it cannot assist in the medical staffing of mental subnormality services. In particular the section on joint appointments is dispiritingly negative, to say nothing of being gratuitously condescending to the many present holders of these posts in the United Kingdom.

Joint appointments are neither new nor rare. We understand that in the past 10 years more than half of the consultant appointments in mental handicap in Scotland, and a substantial number of those in England and Wales have been on this basis, and we would argue that valuable expertise in child and general psychiatry, as well as in paediatric medicine, which might otherwise have been deployed in other fields, has been recruited to mental handicap in this way. We know of no evidence which suggests that the quality of care given to patients is in any way diminished by the joint nature of these appointments, and we resent statements which imply that it has been.

Joint appointments in Scotland, and we suspect also in England and Wales, have widened the entry point to senior medical staffing in the field of mental deficiency, have helped to bring psychiatric trainees of calibre into the specialty, and have enhanced research.

As the statement of the Executive Committee of the MD Section stands, we think it is more likely to deter than to encourage recruitment of psychiatric and other consultants to the care of the mentally handicapped.

Royal Dundee Liff and Strathmartine Hospitals

Hector C. FOWLIE Dundee

Also signed by: P. G. Aungle, W. Baird; B. R. Ballinger; I. R. C. Batchelor; J. Chick; H. Davies; R. Drummond; S. Fazlulla; W. Fraser; M. K. P. Henderson; R. I. Kennedy; A. Lodge; M. McLeod; G. J. Naylor; M. RenNiE; A. H. ReID; B. Rrrson; H. Ross; A. H. W. SMrth; A. Zeally.

\section{Treatments in psychiatry-Who decides?}

DEAR SIR

In the SK \& F publication of the proceedings of a recent APIT meeting (1980), Mr Larry Gostin asserts that there must be 'lay, legal and social assessment' of patients refusing consent to treatment.

In this and the related matter of consent to hospitalization we do not yet know whether some of the changes proposed in the Government White Paper (DHSS, 1978) will be translated into law despite being opposed or rejected by the Royal College (Bulletin, 1979). However, it is evident that pressures for these changes persist.

'Lay, legal and social' assessments do in fact take place now in the case of Hospital Orders under Sections 60 and 65 and of the Mental Health Review Tribunals. But the Royal Commission of 1953-7, and Parliament when it passed the 1959 Act, thought it sensible and appropriate that for noncriminal patients a magistrate should not necessarily be 